\title{
Measuring the Impact of General Allocation Funds, Labor and Government Expenditures on Economic Growth
}

\section{Ecces: \\ Economics Social and Development Studies}

\author{
Andi Lopa Ginting * \\ Department of Economics Development, \\ Faculty of Economy Universitas Terbuka \\ South Tangerang City, Banten, 15418, Indonesia* \\ e-mail: Andi.lopaginting@ecampus.ut.ac.id*
}

(Article history) Received: 2021-04-09, Revised: 2021-12-30, Accepted:2021-12-30, Available online: 2021-12-31, DOI: DOI: 10.24252/ecc.v7i1.13382, Stable URL: http://journal.uin-alauddin.ac.id/index.php/ecc/index

\section{Abstract: Measuring the Impact of General Allocation Funds, Labor and Government Expenditures on Economic Growth}

This study aims to analyze the effect of General Allocation Funds, Labor and Government Expenditures on Economic Growth in East Kotawaringin Regency. The research method used in this research is a descriptive-quantitative research approach. The analytical tool used in his study is multiple linear regression with the $t$ test, $F$ test, and the coefficient of determination test. The results of this study indicate that partially the variables of the General Allocation Fund and Government Expenditures have a significant effect on Economic Growth in East Kotawaringin Regency. While the Labor variable does not have a significant effect on Economic Growth in East Kotawaringin Regency. Simultaneously, the variables of the General Allocation Fund, Labor, and Government Expenditures together have an effect on the Economic Growth variable. The implications of this research include, among others, to encourage the economy of East Kotawaringin Regency, the general allocation fund should be increased for the advancement and improvement of economic growth as well as improving the quality of the Laborforce in the East Kotawaringin area.

Keywords: Economic Growth; General Allocation Fund; Government Expenditure; Labor

\section{INTRODUCTION}

Economic progress that takes place in an area can be seen from the existing economic growth by measuring the level of comparison of gross domestic product from a specified year compared to the previous year (Suindyah, 2011). A country can be said to be facing economic development, namely if there is an increase in real GNP (Tutupoho, 
Andi Lopa Ginting, Measuring the Impact of General Allocation Funds, Labor and Government Expenditures on Economic Growth

2019). In the system of increasing real GNP, a country certainly needs an economic development that is accompanied by income distribution, poverty alleviation, and unemployment, as a result where economic development can be said to be increasing economic development. Not only that, the existence of an increasing economic development also causes more and more public parties to participate in enjoying the economic development. The economic growth of a country or a region that continues to show improvement illustrates that the economy of the country or region is developing well (Amin, 2007). The existence of a perfect economy can lead to stable price conditions so that there are greater job opportunities for every unemployed person. But the fact is that in a region's economic situation, it usually faces an unstable situation. The economy cannot develop continuously indefinitely, meaning that economic life may be marked by an instability within a certain time span, and cause economic activity to suddenly decline, which is then followed by a turning point or high point or what is commonly called the momentum of the economy upper turning point (Dong and Fan, 2020; Saputri and Anwar, 2019).

Economic growth is one of the indicators which is very meaningful to identify and assess the results of the development carried out, especially on the economic side. The basic dimensions of a successful development, as well as the results of economic growth, can later be felt by the community in general, to the bottom layer, where the process uses government intervention and the existing free market system (Acheampong et al., 2021; Arina et al., 2021; Cooley and Prescott, 2021; Kotz et al., 2021; Mose, 2021; Su et al., 2021).

In previous research, Wardani (2021) said that districts or cities in East Java have not described good economic growth, because not all areas in the city/regency have adequate economic growth, and income levels are not evenly distributed as a whole. For this reason, nationally, East Java Province cannot be said to be a Regency/City that has succeeded in distributing its income. To encourage more accelerated economic growth, Fathur (2021) states that the state must be able to facilitate various regulations and deregulations that are able to support economic activities. For a developing country, such as Indonesia, the rapid flow of capital is a good opportunity to get investment to drive the economy, where the process of economic formation that is being carried out in this country is a sustainable effort that can be expected to create a prosperous and just nation. according to Pancasila. Where, to achieve these goals, efforts are made in the national development process to focus on economic development. Economic development is not only 


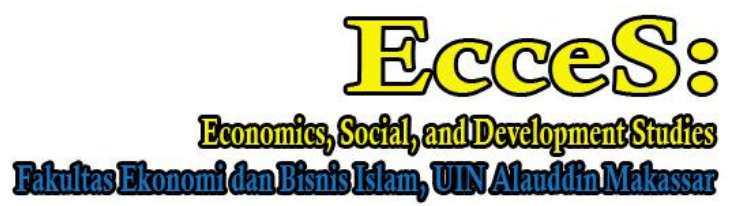

Volume 8 Number 2 Ed. Desember 2021 : page: 195-214 p-ISSN: 2407-6635 e-ISSN : 2580-5570

the main task and function of the central government and even nationally, but more than that, it can be a barometer for each region to carry out development from the lowest level to the center. This is because the economic development of a country is also influenced by economic developments in the respective regions. Therefore, the economic development of a region/region can become a very important concern and is not only prioritized for local governments, but also in the central government (Brilyawan and Santosa, 2021).

One of the instruments for carrying out development is the ability of local governments to manage potential existing fiscal capacity (Aldama, 2018; Auerbach and Murphy, 2020; Dweck et al., 2020; Enami et al., 2019; Halimanjaya, 2019; Lee, 2019; Luka, 2019; Ogbuagu and Ewubare, 2019; Puig et al., 2019; Zhou and Xie, 2019). This has been attempted by the East Kotawaringin Regency government, through the management of the General Allocation Fund (GAF). Growth and total realization of funds or general allocation costs Kab. Kotawaringin Timur, which is the largest general allocation fund in Central Kalimantan Province, however is uncertain in nature, this is due to spending and other income factors. In reality, the general allocation fund for the East Kotawaringin area of Central Kalimantan Province, experiences periodic fluctuations that affect economic development, labor and realization of state expenditures.

Figure 1. Economic Growth of East Kotawaringin Regency in 2005-2019

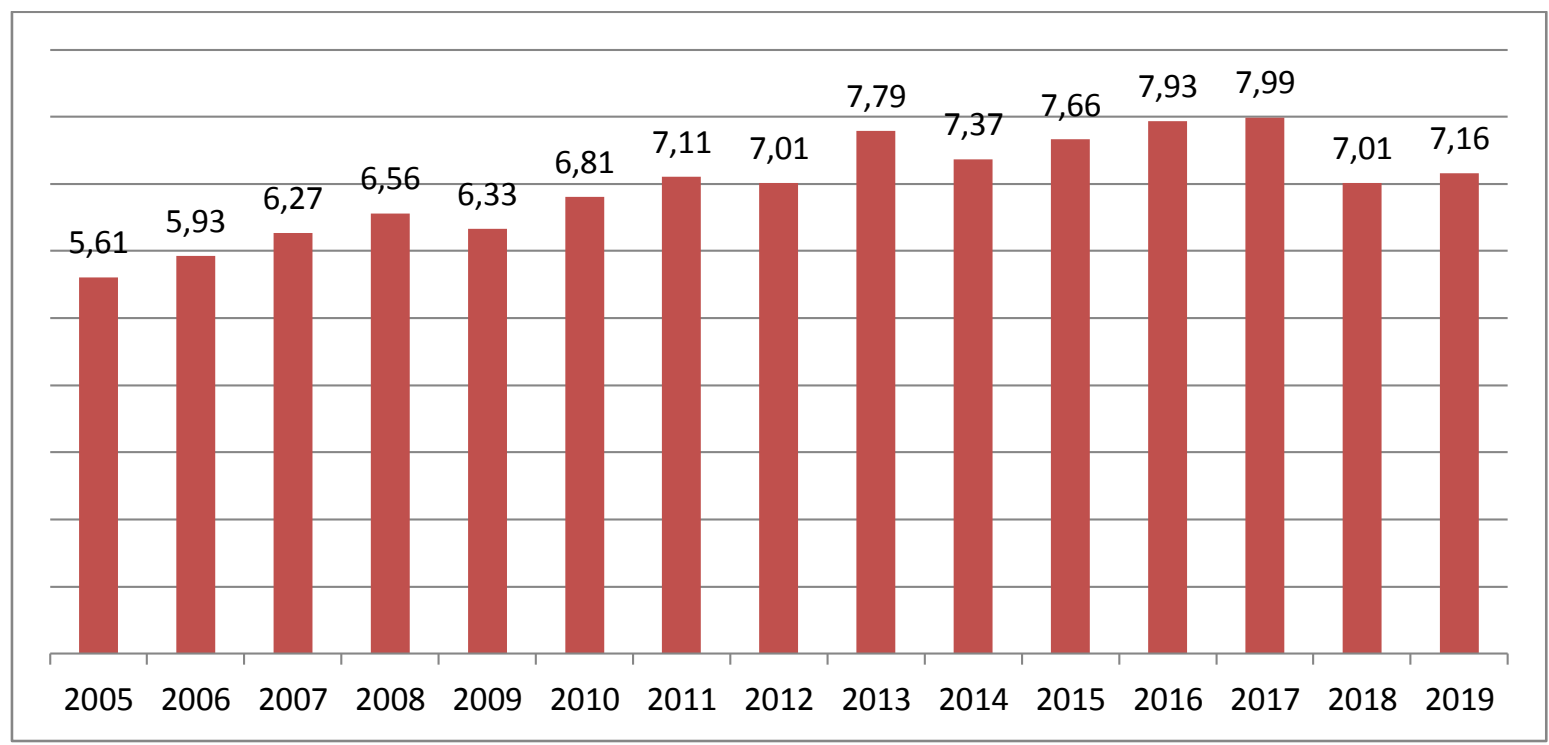

Source: BPS Kotawaringin Timur Regency, 2020.

The level of economic development achieved by a country can be measured or seen based on the development of its real national income. East Kotawaringin Regency is a 
Andi Lopa Ginting, Measuring the Impact of General Allocation Funds, Labor and Government Expenditures on Economic Growth

district whose economy is quite advanced from all districts in the province of Central Kalimantan, although it is also inseparable from various obstacles and challenges in the process of economic development. Various problems of poverty, unemployment, low capital, to the low quality of human resources. Therefore, various economic development policies are continuously pursued to achieve optimal economic development. The economic growth of East Kotawaringin Regency has been quite volatile in the last 15 years. The economic growth of this area reached 5.61 percent in 2005 and increased to 7.16 percent in 2019. It seems that the regional economy tends to increase from year to year.

Optimal economic development can be linked to economic policies that can be used as guidelines for regional economic policies, which have reviewed the implementation of their policies, so that regional policies will be optimized related to the strategic situation and condition of the population in an area, by looking at the advantages and disadvantages. existing natural resources. Indirectly, sustainable economic development can be directly carried out as a form of support for the regional economy, which continues to be pursued as a priority for national development in general, such as education, health and others. This is institutional and very beneficial for the economic growth of a region (Al-Qudah et al., 2021; Ehigiamusoe and Samsurijan, 2021; Gruzina et al., 2021; Langroodi, 2021; Pradhan et al., 2021; Pulido-Fernández and Cárdenas-García, 2021; Stokan et al., 2021).

Economic development can be carried out by encouraging the lower class or poor people, through public policy policies that lead to the correction of market failures that have occurred so far, so that existing economic development can contribute effectively to growth and poverty reduction, so that in the end the resulting economic growth can create new and more inclusive jobs (Kustanto, 2021). In addition to carrying out development with public policies, of course, it can also be pursued with economic empowerment programs with the support of the government's priority programs for national economic recovery. The novelty of this research is that the government's fiscal capacity and government spending become new variables, to see how far these variables affect economic growth.

\section{LITERATUR REVIEW}

According to Zhang et al., (2021) According to classical economists, there are four factors that influence economic growth, namely population, total stock of goods and capital, land area and natural wealth and the level of technology used. Population growth is related to economic growth which is viewed as a factor of production, an increase in population will 


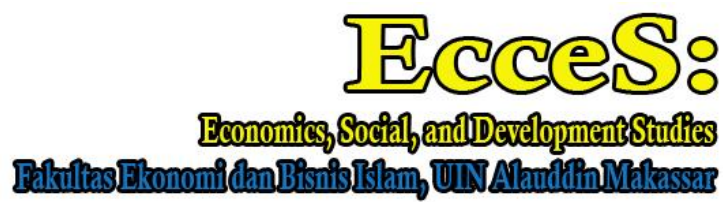

Volume 8 Number 2 Ed. Desember 2021 : page: 195-214 p-ISSN: 2407-6635 e-ISSN : 2580-5570

increase the number of the labor force. The more the Laborforce (labor) the more productive the productive force will be, so that it will increase production. In addition, high economic growth will occur if the free market system works optimally without excessive government intervention (Aligica, 2017; Capitalism and Elusive, 2015; Jackson, 2016; Konya et al., 2017; Preston and Silke, 2017; Prokopijević and Tasić, 2015; Šíma and Nikodym, 2015).

But that is different from Solow's view (in Ball and Mankiw, 2021) that the neo classical economic growth model, asserts that economic growth will be achieved if there is output growth. Output growth occurs when two input factors, namely capital and labor are combined, while the technological factor is considered constant (unchanged). However, the condition for achieving real economic growth requires collaboration between a free market system with adequate regulations, in other words, invisible hands and visible hands run in parallel (Attar, 2021; Ball and Mankiw, 2021; Cooley and Prescott, 2021; Keen, 2021; Nikolaos and Tsaliki, 2021; Rumanzi et al., 2021; Spataro and Martini, 2021; W.-B. Zhang, 2021a, 2021b, 2021c).

According to Kuznets (in Ongan et al., 2021) Economic growth is an increase in the long-term capacity of the country concerned, to provide various economic goods to its population. Economic growth cannot be separated from capital or labor and technology. Provision of capital resources is very necessary in the implementation of development. This source of funds is realized in the form of investment, both domestic and foreign investments (Bashir et al., 2021; Boubellouta and Kusch-Brandt, 2021). This is very necessary to support economic growth, as well as job opportunities. Investment funds can be obtained from the government, the public (private), foreign loans and foreign private investment (Sirajudeen et al., 2021). Economic growth is one indicator of a country's economic progress. To pursue economic growth, it is necessary to support multidimensional activities which include socioeconomic structural support, as well as all domestic institutions, besides that it is important to pursue accelerated economic growth, especially more inclusive growth, which is able to reduce income inequality and poverty (Claude, 2001; Furubotn and Richter, 2008; Ménard and Shirley, 2014; Rutherford, 2001; Samuels, 1984, 1984; Wagner-Tsukamoto, 2008).

Regarding government spending, it is very important to realize the desired economic growth. The views related to this matter, namely the government spending model in view of the Rostow (2021) This model connects the development of government spending with the 
Andi Lopa Ginting, Measuring the Impact of General Allocation Funds, Labor and Government Expenditures on Economic Growth

stages of economic development which are distinguished between early, intermediate, and advanced stages. At the beginning of economic development, the percentage of government investment to total investment is large because at this stage the government must provide infrastructure such as education, health, transportation infrastructure and so on. In the middle stage of economic development, government investment is still needed to increase economic growth in order to take off, but at this stage the role of private investments has grown. Musgrave argues that in a development process, private investment as a percentage of GDP is getting bigger and the percentage of government investment as a percentage of GNP will be getting smaller. At a further economic level, Rostow states that in economic development, government activities shift from providing infrastructure to spending on social activities such as old age welfare programs, public health service programs, and so on. (Cerny, 2014; Kandiko, 2010; Kotz, 2002; Mammadov, 2016; Passas, 2017; Peck, 2017; Series, 2013).

But that is different from Keynes's view (in Bossone, 2021a) that government spending can increase employment opportunities, which can be explained from the point of view, namely Keynes's theory refuting classical theory. Classical theories put forward their view of employment opportunities, namely that the level of output and the equilibrium price can only be achieved if the economy is at the level of full employment. Meanwhile, for Keynesians, a balance with full employment cannot be achieved through a free market mechanism alone, it must be driven by government spending (Backhouse, 2021; Born et al., 2021; Bossone, 2021a, 2021b; Correa, 2021; Eggertsson and Petracchi, 2021; Nofrianto et al., 2021; Olanrewaju and Funlayo, 2021). According to Born et al., (2021) government spending can describe a form of government policy. If the government has set a policy to purchase a service or goods, then the government's expenditure can represent consumption that is able to move the regional economy. Regarding the theory about government spending that triggers an increase in consumption, it can be micro or macro (Haini and Loon, 2021; Nofrianto et al., 2021; Olaoye and Afolabi, 2021; Popescu, 2021; Samuel and Oruta, 2021; D. Zhang et al., 2021).

\section{METHODS}

To explore the extent of the relationship between variables, the approach used in this study is a quantitative descriptive approach, to determine for sure the effect of the General Allocation Fund, labor variables, and government spending on economic growth in East Kotawaringin Regency, Central Kalimantan Province. The reason for choosing the 


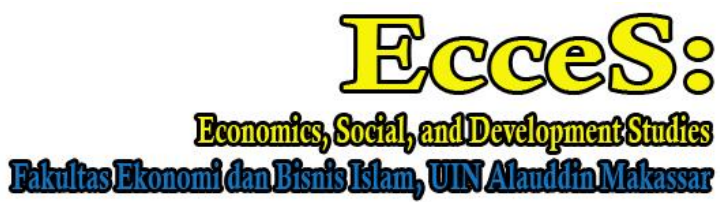

Volume 8 Number 2 Ed. Desember 2021 : page: 195-214 p-ISSN: 2407-6635 e-ISSN : 2580-5570

research location is because the area under study is a buffer city in Central Kalimantan Province, which has a major contribution to the economic growth of the region. The data used is secondary data sourced from BPS Kotawaringin Timur Regency and Central Kalimantan Province with a time duration of 2005-2019 or 15 years.

The data analysis method used in this study is based on multiple regression analysis. Regression analysis is a scientific research to evaluate and explain the relationship and relationship between a (dependent variable) dependent variable and (independent variable) independent variable whose purpose is to predict or estimate the value of the dependent variable on the independent variable (Giel and Dąbrowska, 2021; Hesamian and Akbari, 2021; Pacifico, 2021; Rusev et al., 2021; Wani et al., 2021; C. Zhang, 2021). The variables in question are general allocation funds which are measured in rupiah units, the labor force is measured in soul units, and government expenditures are measured in rupiah units, each of which is an independent variable and economic growth as the dependent variable is measured in percent units. Multiple linear regression analysis (multiple regression) is used to determine the effect between variables, with the following equation:

Grwth $=\beta 0$ GnrlFnd $_{t}{ }^{\beta 1}$ Lbrfrce $_{t}{ }^{\beta 2}$ Gspend $_{t}{ }^{\beta 3} \mu$

To measure the existing regression coefficients, changes are made in the form of a partial natural logarithm (In) into the model, which can be explained based on the following equation:

LnGrwth $=$ Ln$_{\beta 0} 0+\beta 1$ LnGnrlFnd $_{t}+\beta 2$ Lbrfrce $_{t}+\beta 3$ Gspend $_{t}+\mu_{t}$

Keterangan:

Grwth

$=$ Economic growth

GnrlFnd

= Realisasi Dana Alokasi Umum

Lbrfrce

= Labor force

Gspend

$=$ Government expenditures

$\beta 0$

= Constanta

Ln

$=$ Natural Logarithm

$\beta 1, \beta 2, \beta 3$,

$=$ Regression Coefficient

$\mathrm{t}$

$=$ Time Series

$\mu$

$=$ Residual 
Andi Lopa Ginting, Measuring the Impact of General Allocation Funds, Labor and Government Expenditures on Economic Growth

\section{RESULT AND DISCUSSION}

General allocation funds are funds sourced from APBN revenues which are allocated with the aim of equitable distribution of financial capacity among regions to fund regional needs in the context of implementing decentralization. General allocation funds are transfers from the center to the regions in the form of "block grants" whose regulatory authority and use are fully delegated to local governments in the context of administering local government.

From year to year the development of general allocation funds in the Kotawaringin Timur district can be seen in the table below:

Table 1. Total Realization of the General Allocation Fund for East Kotawaringin Regency

\begin{tabular}{cc}
\multicolumn{2}{c}{$2005-2019$ (Rupiah) } \\
\hline Year & General Allocation Fund \\
2005 & 200.000 .000 .000 \\
2007 & 361.003 .000 .000 \\
2008 & 432.612 .355 .000 \\
2009 & 445.665 .199 .800 \\
2010 & 457.814 .163 .000 \\
2011 & 459.745 .862 .000 \\
2012 & 531.968 .763 .000 \\
2013 & 618.026 .440 .000 \\
2014 & 708.665 .917 .000 \\
2015 & 778.842 .792 .000 \\
2016 & 788.804 .313 .000 \\
2017 & 832.526 .925 .000 \\
2018 & 821.559 .562 .000 \\
2019 & 820.559 .562 .000 \\
\hline
\end{tabular}

Source: BPS Kotawaringin Timur Regency, 2020.

In the table, it can be seen that the general allocation fund for the East Kotawaringin district during the years 2005-2009 has continued to increase from year to year, where in 2005 it was Rp. 200,000,000,000, in 2006 it increased to Rp.361,003,000,000, in 2007 it became Rp.432,612,355,000, in 2015 it reached Rp.788.804,313,000 and in 2019 it 


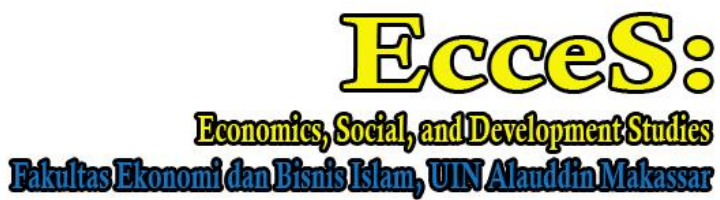

Volume 8 Number 2 Ed. Desember 2021 : page: 195-214 p-ISSN: 2407-6635 e-ISSN : 2580-5570

increased to Rp. 843,967,781,000. The general allocation fund for the last 15 (fifteen) years has continued to increase, this is due to the increase in Domestic Revenue and this has prompted the central government to continue to increase the general allocation fund for the East Kotawaringin district.

To analyze the effect of labor, the number of labor force per year can be used. In the table on the number of work force in East Kotawaringin Regency, it can be seen that the Laborforce in East Kotawaringin Regency during the period 2005-2019 experienced fluctuations. To see the development of the East Kotawaringin district laborforce, see the table below:

Table 2. Number of Laborforce in East Kotawaringin Regency

Years 2005-2019 (people)

\begin{tabular}{lc}
\hline Year & Laborforce \\
\hline 2005 & 119.345 \\
2006 & 120.743 \\
2008 & 152.123 \\
2009 & 140.666 \\
2010 & 152.454 \\
2011 & 179.716 \\
2012 & 191.693 \\
2013 & 170.336 \\
2014 & 170.463 \\
2015 & 192.945 \\
2016 & 206.026 \\
2017 & 216.102 \\
2018 & 254.285 \\
2019 & 227.918 \\
\hline
\end{tabular}

Source: BPS Kotawaringin Timur Regency, 2020.

In 2005 the number of the labor force of East Kotawaringin Regency was 119,345 people, then it increased the following year to 120,743 people in 2006 . Until 2011 this number continued to increase to 191,693 people, and in 2012 it decreased to 170,336 people, and in 2012 it decreased to 170,336 people. In 2019, it increased again to 230,323 
Andi Lopa Ginting, Measuring the Impact of General Allocation Funds, Labor and Government Expenditures on Economic Growth

people. The number of the Laborforce in the last 15 (fifteen) years has fluctuated and this is also because the labor force of East Kotawaringin Regency still has to be increased to encourage economic growth in East Kotawaringin Regency.

Based on the results of the documentation, the data obtained from the East Kotawaringin district government expenditures are as follows. To understand the condition of local government expenditure, it can be translated as the realization of total regional expenditure in East Kotawaringin Regency, which is expressed in rupiah.

Table 3. Realized Government Expenditures for East Kotawaringin Regency 2005-2019 (Rupiah)

\begin{tabular}{ll}
\hline Tahun & Government Expenditures \\
\hline 2005 & 335.520 .908 .000 \\
2006 & 455.628 .234 .000 \\
2007 & 571.322 .408 .000 \\
2008 & 660.906 .480 .639 \\
2009 & 721.837 .040 .662 \\
2010 & 664.240 .295 .017 \\
2011 & 761.964 .044 .565 \\
2012 & 846.668 .159 .561 \\
2013 & 1.177 .022 .175 .993 \\
2014 & 1.439 .634 .544 .065 \\
2015 & 1.309 .277 .060 .826 \\
2016 & 1.540 .102 .862 .809 \\
2017 & 1.512 .911 .458 .534 \\
2018 & 1.876 .990 .951 .800 \\
2019 & 1.928 .043 .545 .627
\end{tabular}

Source: BPS Kotawaringin Timur Regency, 2020.

In 2005, the expenditure of the Kotawaringin Timur district government reached Rp. $335,520,908,000$, in 2006 increased by Rp. 455,628,234,000, this trend continued to increase until 2009. In 2010, it decreased by Rp. $664,240,295,017$, and again experienced an increase until 2019, which was at the same time the highest number in the last 15 years, with a total government expenditure of Rp.1,928,043,545,627.

Related to the findings of this study, it is described in (t-test) the results of hypothesis testing in a partial way in order to understand whether or not there is an influence individually, rather than all independent variables (X3, X2 and $\mathrm{X} 1)$ on the 


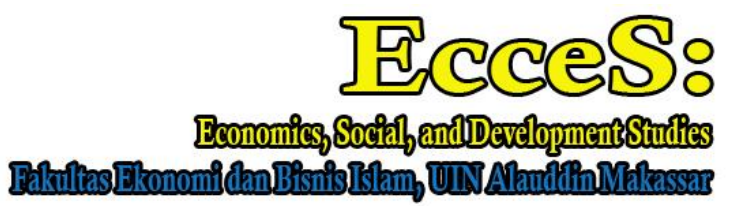

Volume 8 Number 2 Ed. Desember 2021 : page: 195-214 p-ISSN: 2407-6635 e-ISSN : 2580-5570

dependent variable $(\mathrm{Y})$ carried out using this method. the comparison between the value of $t$ _(table) with t_count or the comparison of its value is significant to the error level ( $a=$ 0.05) at the 95 percent confidence level. Where the value $t_{-}$(table ) is obtained from $\mathrm{t}_{-}($table $)=\mathrm{t}(\mathrm{a} / 2 ; \mathrm{n}-\mathrm{k}-1)$. Value $\mathrm{t}_{-}($table $)=\mathrm{t}(0.025 ; 15-3-1)=2,201$. The provisions of this test are, if the value is t-table t-count so that it is said that the independent variable has an influence on the dependent variable, then $\mathrm{Ha}$ is accepted and $\mathrm{HO}$ is rejected so that it is interpreted as the acceptance of the hypothesis; also vice versa if t-table t-count, thus $\mathrm{Ha}$ is rejected and $\mathrm{HO}$ is accepted, it means that the hypothesis is rejected. Based on the table above, the calculation of multiple linear regression is obtained, which is how to use the $t$ test (testing by partial method):

Table 4. $\mathrm{t}$ test results

\begin{tabular}{|c|c|c|c|c|c|c|}
\hline \multirow{2}{*}{\multicolumn{2}{|c|}{$\begin{array}{l}\text { Indevendent } \\
\text { Variabel }\end{array}$}} & \multicolumn{2}{|c|}{ Unstandardized Coefficients } & $\begin{array}{c}\text { Stand } \\
\text { ardize } \\
\mathrm{d} \\
\text { Coeffi } \\
\text { cients }\end{array}$ & $\mathrm{t}$ & Sig. \\
\hline & & B & Std. Error & Beta & & \\
\hline 1 & (Constant) & 3.553 & .483 & & 7.349 & .000 \\
\hline & DAU $(X 1)$ & .004 & .001 & 1.156 & 4.452 & .001 \\
\hline & $\begin{array}{l}\text { Tenaga Kerja } \\
(\mathrm{X} 2)\end{array}$ & .001 & .004 & .032 & .139 & .892 \\
\hline & $\begin{array}{l}\text { Pengeluaran } \\
\text { Pemerintah } \\
\text { (X3) }\end{array}$ & .001 & .000 & .410 & 2.869 & .015 \\
\hline
\end{tabular}

Source: Primary data output after processing, 2020.21

Based on the table above, it is analyzed that the t-count value as a variable (X1) is $4.452>$ t-table is 2.201 at the ninety-five percent confidence level $(a=0.05$ ) where the significance value is $<0.05$, i.e. $(0.001<0,05)$. Thus $\mathrm{Ha}$ is accepted while Ho is rejected, meaning that partially the variable (X1) has a significant influence on economic growth in Kab. East Kotawaringin. Meanwhile, for the variable (X2) worth $0.139<$ t-table worth 2.201 according to the maximum result of $95 \%(a=0.05)$, where the significance value is $>0.05$ i.e. $(0.892>0.05)$. So $\mathrm{HO}$ is accepted and $\mathrm{Ha}$ is rejected, meaning that partially the Labor variable (X1) has no significant effect on economic growth in East Kotawaringin Regency. For the government expenditure variable (X3) worth $2.869>$ t-table worth 2.201 , at the $95 \%$ confidence level $(a=0.05)$ where the significance value $<0.05$ is $(0.015$ 
Andi Lopa Ginting, Measuring the Impact of General Allocation Funds, Labor and Government Expenditures on Economic Growth

$<0.05$ ) so rejecting $\mathrm{HO}$ also accepts $\mathrm{Ha}$. Thus, partially the variable (X3) of government expenditure has a significant influence on economic growth in East Kotawaringin district.

\section{Impact of the General Allocation Fund on Economic Growth in East Kotawaringin Regency.}

The results of this study show that the general allocation fund has a positive and significant impact on economic growth in Kab. East Kotawaringin. This describes a significant value of 0.001 < the value (0.05). Research result Handoyo et al., (2020) found the same thing that the general allocation fund had a significant impact on economic growth. This shows that the addition to the general allocation fund has resulted in an increase in the level of economic growth in Indonesia. General allocation funds become one of the levers to move the economy, which is a budget whose source comes from APBN funds, where allocations can be made so that the aim is to equalize the ability of each region to be able to finance regional needs or expenditures, which is also part of the decentralization scheme.

In this study, it was found that the general allocation fund had a significant influence on economic growth in the Kotawaringin Timur Regency. Where in 2005-2019 the general allocation fund for East Kotawaringin continued to increase every year and was followed by economic growth. So, to encourage the economy of East Kotawaringin Regency, the general allocation fund must be increased for the progress and growth of East Kotawaringin Regency.

\section{The Impact of Labor on Economic Growth in East Kotawaringin Regency}

The results of this research show that the workforce does not have a significant impact but shows a positive value on economic growth in East Kotawaringin Regency. This is shown by the significance value of $0.892>$ the value of (0.05). Based on the value of the labor variable, it can be stated that the labor force of East Kotawaringin Regency has a role in economic growth but is not significant. This is in line with the findings Kamaluddin and Anwar (2017) labor variable has no effect in increasing production. It should be noted that a sustainable increase in production can increase economic growth. Based on the results of observations, the number of the East Kotawaringin district's workforce from 2005-2019 experienced fluctuations in the number of the workforce. In addition, part of the workforce in East Kotawaringin Regency is dominated by workers who do not have sufficient expertise, so that although there is a large number of workforce, it does not support economic growth. For this reason, the government needs to encourage an increase in quality workforce, not just to prepare a large number of workers, so that they 


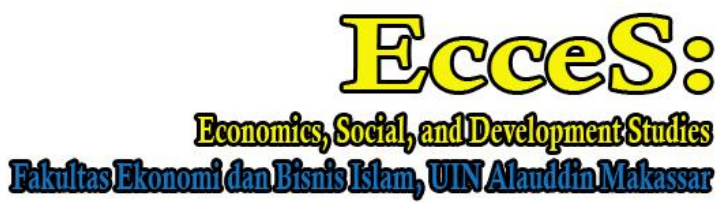

Volume 8 Number 2 Ed. Desember 2021 : page: 195-214 p-ISSN: 2407-6635 e-ISSN : 2580-5570

can be absorbed in the labor market. The government also needs to increase innovation among the workforce (Papadakis et al., 2020). In fact, the contribution of a quality workforce is sustainable to real GDP growth and economic growth, and supports development in the short and long term (Christiano et al., 2020).

\section{Impact of Government Expenditures on Economic Growth in Kotawaringin Timur Regency}

Based on the results of this study, it is known that government spending has a positive and significant impact on economic growth in East Kotawaringin Regency. This describes a significance value of $0.015<$ the value $(0.05)$. The results of this study are in line with the results of this study Ruslam and Anwar (2020) found that government spending has a significant and positive relationship on economic growth. From the findings of this research, it can be understood that in order to increase the level of economic growth, it is necessary to increase the amount of budget or development expenditure funds because it can increase the level of productivity, so as to increase the amount of output or production. This situation is also expected to be able to provide added value, which in turn can increase economic growth. Government spending is one of the things that can accelerate economic growth which in turn can increase the income of the population and move the wheels of the economy. For this reason, the government of East Kotawaringin Regency must accelerate the amount of government spending in order to be able to encourage and increase the economic growth of East Kotawaringin Regency.

\section{CONCLUSION}

Based on the results of this study, it was found that the general allocation fund had a significant impact on economic growth in East Kotawaringin Regency. Where in 2005-2019 the East Kotawaringin general allocation fund seemed sustainable, continued to experience a significant increase and was followed by an increase in economic growth. In contrast to the labor variable, it shows a relationship that does not have a significant impact but shows an influence on economic growth in East Kotawaringin Regency. For the government expenditure variable, it has a significant and positive impact on economic growth in East Kotawaringin Regency, Central Kalimantan Province. The implications of this research include, among others, to encourage the economy of East Kotawaringin Regency, the general allocation fund should be increased for the advancement and improvement of 
Andi Lopa Ginting, Measuring the Impact of General Allocation Funds, Labor and Government Expenditures on Economic Growth

economic growth as well as improving the quality of the workforce in the East Kotawaringin area.

\section{REFERENCES}

Acheampong, A.O., Boateng, E., Amponsah, M., Dzator, J., 2021. Revisiting the economic growth-energy consumption nexus: Does globalization matter? Energy Econ. 102, 105472.

Al-Qudah, A.A., Al-Okaily, M., Alqudah, H., 2021. The relationship between social entrepreneurship and sustainable development from economic growth perspective: 15 'RCEP'countries. J. Sustain. Financ. Invest. 1-18.

Aldama, P., 2018. Fiscal Policy in the US: Sustainable After All ?

Aligica, P.D., 2017. Public administration and the classical liberal perspective: Criticism, clarifications, and reconstruction. Adm. Soc. 49, 530-551.

Amin, A., 2007. Pengaruh inflasi dan pertumbuhan ekonomi terhadap pengangguran di Indonesia. J. Inflasi dan Pengangguran 1.

Arina, M.M., Koleangan, R.A.M., Engka, D.S.M., 2021. Pengaruh Pendapatan Asli Daerah, Dana Bagi Hasil, Dana Alokasi Umum, Dan Dana Alokasi Khusus Terhadap Pertumbuhan Ekonomi Kota Manado. J. Pembang. Ekon. Dan Keuang. Drh. 20, 26-35.

Attar, M.A., 2021. Growth, distribution and dynamic inefficiency in Turkey: An analysis of the naïve neoclassical theory of capital. Struct. Chang. Econ. Dyn. 59, 20-30.

Auerbach, A.J., Murphy, D., 2020. No Title.

Backhouse, R.E., 2021. Zachary Carter, The Price of Peace: Money, Democracy, and the Life of John Maynard Keynes. Fconomia. Hist. Methodol. Philos. 511-518.

Ball, L.M., Mankiw, N.G., 2021. Market power in neoclassical growth models. National Bureau of Economic Research.

Bashir, M.F., Ma, B., Bashir, M.A., Shahzad, L., 2021. Scientific data-driven evaluation of academic publications on evironmental Kuznets curve. Environ. Sci. Pollut. Res. 1-18.

Born, B., D'Ascanio, F., Müller, G.J., Pfeifer, J., 2021. Mr. Keynes meets the classics: government spending and the real exchange rate. ifo Working Paper.

Bossone, B., 2021a. Exercising Economic Sovereignty in Today's Global Financial World: The Lessons from John Maynard Keynes.

Bossone, B., 2021b. Globalization of capital, erosion of economic policy sovereignty, and the lessons from John Maynard Keynes. Rev. Keynes. Econ. 9, 512-520.

Boubellouta, B., Kusch-Brandt, S., 2021. Relationship between economic growth and 


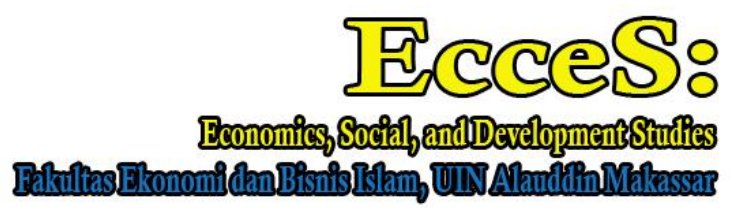

Volume 8 Number 2 Ed. Desember 2021 : page: 195-214 p-ISSN: 2407-6635 e-ISSN : 2580-5570

mismanaged e-waste: Panel data evidence from $27 \mathrm{EU}$ countries analyzed under the Kuznets curve hypothesis. Waste Manag. 120, 85-97.

Brilyawan, K., Santosa, P.B., 2021. Pengaruh Infrastruktur Sosial Dan Ekonomi Terhadap

Pertumbuhan Ekonomi Indonesia Tahun 2015-2019. Diponegoro J. Econ. 10.

Capitalism, P., Elusive, S., 2015. Revista Economica 67:6 (2015) 6, 21-29.

Cerny, P.G., 2014. Globalization and the resilience of neoliberalism. Crit. Policy Stud. 8, 359362.

Christiano, L.J., Trabandt, M., Walentin, K., 2020. Review of Economic Dynamics Involuntary unemployment and the business cycle th. Rev. Econ. Dyn. 1, 1-29.

Claude, B., 2001. IN 8.

Cooley, T.F., Prescott, E.C., 2021. 1. Economic Growth and Business Cycles. In: Frontiers of Business Cycle Research. Princeton University Press, pp. 1-38.

Correa, R., 2021. A Classical-Keynes Model of Money and Finance for Transiting Economies. Indian Econ. J. 00194662211017269.

Dong, Y., Fan, C., 2020. The role of China's aid and ODI in the economic growth of African countries. Emerg. Mark. Rev. 100713.

Dweck, E., Vianna, M., Barbosa, A., 2020. ScienceDirect Discussing the role of fiscal policy in a demand-led agent-based growth model $* 21,185-208$.

Eggertsson, G.B., Petracchi, C., 2021. Mr. Keynes and the "Classics"; A Suggested Reinterpretation. National Bureau of Economic Research.

Ehigiamusoe, K.U., Samsurijan, M.S., 2021. What matters for finance-growth nexus? A critical survey of macroeconomic stability, institutions, financial and economic development. Int. J. Financ. Econ. 26, 5302-5320.

Enami, A., Lustig, N., Taqdiri, A., Enami, A., 2019. Fiscal policy, inequality, and poverty in Iran : assessing the impact and effectiveness of taxes and transfers the impact and e ff ectiveness of taxes and transfers 8120 .

Fathur, A., 2021. Implikasi Linear Dan Nonlinear Pertumbuhan Ekonomi Terhadap Ketimpangan Pendapatan Di Indonesia.

Furubotn, E.G., Richter, R., 2008. The new institutional economics - A different approach to economic analysis. Econ. Aff. 28, 15-23.

Giel, R., Dąbrowska, A., 2021. Estimating Time Spent at the Waste Collection Point by a Garbage Truck with a Multiple Regression Model. Sustainability 13, 4272. 
Andi Lopa Ginting, Measuring the Impact of General Allocation Funds, Labor and Government Expenditures on Economic Growth

Gruzina, Y., Firsova, I., Strielkowski, W., 2021. Dynamics of Human Capital Development in Economic Development Cycles. Economies 9, 67.

Haini, H., Loon, P.W., 2021. Does Government Ideology Affect the Relationship Between Government Spending and Economic Growth? Econ. Pap. A J. Appl. Econ. policy. Halimanjaya, A., 2019. The Political Economy of Indonesia 's Renewable Energy Sector and Its Fiscal Policy Gap 7, 45-64.

Handoyo, R.D., Erlando, A., Septiyanto, I., 2020. Dampak Faktor Eksternal Terhadap

Pertumbuhan Ekonomi Indonesia. EcceS (Economics, Soc. Dev. Stud. 7, 1.

Hesamian, G., Akbari, M.G., 2021. A robust multiple regression model based on fuzzy random variables. J. Comput. Appl. Math. 388, 113270.

Jackson, B., 2016. The Routledge Handbook of Neo-Liberalism 1-17.

Kamaluddin, K., Anwar, A.F., 2017. Faktor-faktor yang Memengaruhi Produksi Jagung di

Desa Tanah Towa Kecamatan Kajang Kabupaten Bulukumba. EcceS (Economics, Soc.

Dev. Stud. 4, 67-76.

Kandiko, C.B., 2010. Neoliberalism in Higher Education: A Comparative Approach. Int. J. Arts Sci. 3, 153-175.

Keen, S., 2021. The appallingly bad neoclassical economics of climate change. Globalizations $18,1149-1177$.

Konya, S., Karaçor, Z., Yardimci, P., 2017. Welfare and Governance Crises of Neoliberal Globalization: the New Institutional Economics Perspective. DIEM Dubrovnik Int. Econ. Meet. 3, 361-380.

Kotz, D.M., 2002. Globalization and neoliberalism. Rethink. Marx. 14, 64-79.

Kotz, M., Wenz, L., Stechemesser, A., Kalkuhl, M., Levermann, A., 2021. Day-to-day temperature variability reduces economic growth. Nat. Clim. Chang. 11, 319-325. Kustanto, A., 2021. The Prevalence Of Stunting, Poverty, And Economic Growth In Indonesia: A Panel Data Dynamic Causality Analysis. Jde (Journal Dev. Econ. 6, 150173.

Langroodi, F.E., 2021. Schumpeter's Theory of Economic Development: a study of the creative destruction and entrepreneurship effects on the economic growth. J. Insur. Financ. Manag. 4.

Lee, M., 2019. Does Population Aging Contribute to Increased Fiscal Spending ? 9, 23-28. Luka, B., 2019. Overcoming The Effects Of Restrictive Fiscal Policy: The Case Of Argentina And Serbia Miloš Todorović Ivan Marković Dijana Grahovac 57, 165-179.

Mammadov, A., 2016. NEO - Liberalizm Theory in International Relations Ziyadhan Hasanov 


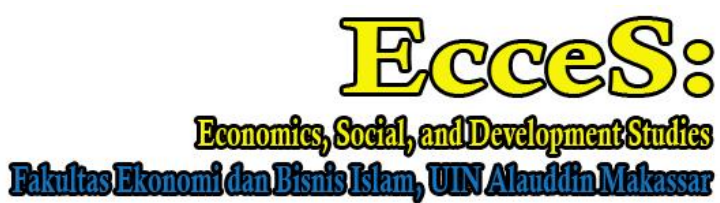

Volume 8 Number 2 Ed. Desember 2021 : page: 195-214 p-ISSN: 2407-6635 e-ISSN : 2580-5570

6959, 291-296.

Ménard, C., Shirley, M.M., 2014. The future of new institutional economics: From early intuitions to a new paradigm? J. Institutional Econ. 10, 541-565.

Mose, N.G., 2021. Determinants of regional economic growth in Kenya. African J. Bus. Manag. 15, 1-12.

Nikolaos, C., Tsaliki, P., 2021. The dynamics of capital accumulation in Marx and Solow. Struct. Chang. Econ. Dyn. 57, 148-158.

Nofrianto, N., Muliana, Y., Cahyadi, A., 2021. The Impact of Islamic Bank Financing, Government Spending, and Investment on Economic Growth in Indonesia. Signifikan J. Ilmu Ekon. 10, 299-310.

Ogbuagu, A.R., Ewubare, D.B., 2019. The Dynamic Correlation between Fiscal Spending on Education , Health , Consumption and Standard of Living in Nigeria 9, 259-267.

Olanrewaju, S.M., Funlayo, A.K., 2021. Public Expenditure and Economic Growth: A Test of Wagner's and Keynes Hypotheses in Nigeria and Angola Economies. Eur. J. Humanit. Soc. Sci. 1, 1-6.

Olaoye, O., Afolabi, O., 2021. Government spending and economic growth: a trivariate causality testing. African J. Econ. Manag. Stud.

Ongan, S., Isik, C., Ozdemir, D., 2021. Economic growth and environmental degradation: evidence from the US case environmental Kuznets curve hypothesis with application of decomposition. J. Environ. Econ. Policy 10, 14-21.

Pacifico, A., 2021. Robust open Bayesian analysis: Overfitting, model uncertainty, and endogeneity issues in multiple regression models. Econom. Rev. 40, 148-176.

Papadakis, N., Amanaki, E., Drakaki, M., Saridaki, S., 2020. Employment/ unemployment, education and poverty in the Greek Youth, within the EU context. Int. J. Educ. Res. 99, 101503.

Passas, N., 2017. Global anomie, dysnomie, and economic crime: Hidden consequences of neoliberalism and globalization in Russia and around the world. Transnatl. Financ. Crime 27, 29-57.

Peck, J., 2017. Jamie Peck 2007-2012.

Popescu, C.C., 2021. Government Spending and Economic Growth: A Cointegration Analysis on Romania. Sustainability 13, 6575.

Pradhan, R.P., Arvin, M.B., Nair, M.S., Hall, J.H., Bennett, S.E., 2021. Sustainable economic 
Andi Lopa Ginting, Measuring the Impact of General Allocation Funds, Labor and Government Expenditures on Economic Growth

development in India: The dynamics between financial inclusion, ICT development, and economic growth. Technol. Forecast. Soc. Change 169, 120758.

Preston, P., Silke, H., 2017. Contrasting conceptions, discourses, and studies of economic inequalities. Int. J. Commun. 11, 4324-4349.

Prokopijević, M., Tasić, S., 2015. Classical liberal economics in the Ex-Yugoslav nations. Econ J. Watch $12,260-273$.

Puig, J.P., Riera-crichton, D., Vegh, C.A., Avellan, L., Berg, A., Fattal, R., Messina, J., Powell, A., Serebrisky, T., Serven, L., Stein, E., Medina, J.P., 2019. Is The Public Investment Multiplier Higher In Developing Countries?

Pulido-Fernández, J.I., Cárdenas-García, P.J., 2021. Analyzing the bidirectional relationship between tourism growth and economic development. J. Travel Res. 60, 583-602.

Rostow, W.W., 2021. 7. The Republic of Korea: My Marginal Association with a Miracle. In: Concept and Controversy. University of Texas Press, pp. 254-261.

Rumanzi, P.I., Turyareeba, D., Kaberuka, W., Mbabazize, R.N., Ainomugisha, P., 2021. Uganda's growth Determinants: A Test of the Relevance of the Neoclassical Growth Theory. Mod. Econ. 12, 107-139.

Rusev, V.N., Abramkin, G. V, Muravyova, E.K., 2021. Multiple regression model for gas consumption in Germany. In: IOP Conference Series: Earth and Environmental Science. IOP Publishing, p. 12033.

Ruslam, R., Anwar, A.F., 2020. Menelusur Relasi Investasi, Konsumsi Rumah Tangga, Pengeluaran Pemerintah dan Sektor Pertambangan terhadap Pertumbuhan Ekonomi. ICOR J. Reg. Econ. 1.

Rutherford, M., 2001. Institutional economics: Then and now. J. Econ. Perspect. 15, 173194.

Samuel, U.D., Oruta, I.L., 2021. Government expenditure and economic growth in Nigeria: A disaggregated analysis. Path Sci. 7, 4022-4035.

Samuels, W.J., 1984. Institutional economics. J. Econ. Educ. 15, 211-216.

Saputri, S.F., Anwar, P.H., 2019. Interelasi Pertumbuhan Ekonomi, Belanja Pendidikan dan Pengangguran Terhadap Tingkat Kemiskinan. EcceS (Economics, Soc. Dev. Stud. 6, 91. Series, E., 2013. Liberalism and Globalization Suciu Titus Lecturer Phd , Transilvania " University of Braşov , Romania , 326-330.

Šíma, J., Nikodym, T., 2015. Classical liberalism in the Czech Republic. Econ J. Watch 12, 274-292.

Sirajudeen, A.O., Law, T.H., Wong, S.V., Jakarni, F.M., Ng, C.P., 2021. The sources of the 


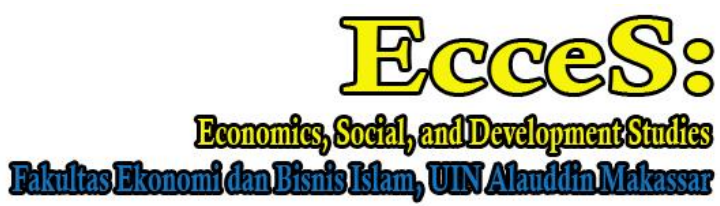

Volume 8 Number 2 Ed. Desember 2021 : page: 195-214 p-ISSN: 2407-6635 e-ISSN : 2580-5570

Kuznets relationship between the road deaths to road injuries ratio and economic growth. J. Safety Res. 78, 262-269.

Spataro, L., Martini, A., 2021. A re-assessment of the relation between saving and economic growth from the marginalist thinkers to the debate of the 1950s.

Stokan, E., Deslatte, A., Hatch, M.E., 2021. Exploring the trade-offs local governments make in the pursuit of economic growth and equity. Urban Aff. Rev. 57, 1084-1114.

Su, C.-W., Song, Y., Umar, M., 2021. Financial aspects of marine economic growth: From the perspective of coastal provinces and regions in China. Ocean Coast. Manag. 204, 105550.

Suindyah, D.S., 2011. Pengaruh Investasi, Tenaga Kerja dan Pengeluaran Pemerintah Terhadap Pertumbuhan Ekonomi Di Propinsi Jawa Timur. Ekuitas 15, 477-500.

Tutupoho, A., 2019. Analisis Sektor Basis dan Sektor Non Basis Terhadap Pertumbuhan Ekonomi Di Provinsi Maluku (Studi Kasus Kabupaten Kota). Cita Ekon. J. Ekon. 13, 118.

Wagner-Tsukamoto, S., 2008. Contrasting the behavioural business ethics approach and the institutional economic approach to business ethics: Insights from the study of Quaker employers - Philosophical foundations/economics \& busines\&s ethics. J. Bus. Ethics 82, $835-850$.

Wani, I., Kumar, H., Rangappa, S.M., Peng, L., Siengchin, S., Kushvaha, V., 2021. Multiple regression model for predicting cracks in soil amended with pig manure biochar and wood biochar. J. Hazardous, Toxic, Radioact. Waste 25, 4020061.

Wardani, H.S., 2021. Pengaruh Jumlah Penduduk, Upah Minimum Regional (Umr), Pengeluaran Pemerintah, Dan Kemiskinan Terhadap Pertumbuhan Ekonomi Di Jawa Timur.

Zhang, C., 2021. Factors Influencing the Allocation of Regional Sci-Tech Financial Resources Based on the Multiple Regression Model. Math. Probl. Eng. 2021.

Zhang, D., Mohsin, M., Rasheed, A.K., Chang, Y., Taghizadeh-Hesary, F., 2021. Public spending and green economic growth in BRI region: Mediating role of green finance. Energy Policy 153, 112256.

Zhang, S., Liu, Y., Huang, D.-H., 2021. Understanding the mystery of continued rapid economic growth. J. Bus. Res. 124, 529-537.

Zhang, W.-B., 2021a. Economic Growth and Human Networking. Izv. J. Varna Univ. Econ. 
Andi Lopa Ginting, Measuring the Impact of General Allocation Funds, Labor and Government Expenditures on Economic Growth

$65,5-25$.

Zhang, W.-B., 2021b. An Integration of Neoclassical Growth Theory and Economic Structural Change with Monopolistic Competition Theory. Bus. Econ. Res. 11, 145-164.

Zhang, W.-B., 2021c. Cournot-Nash Equilibrium and Perfect Competition in the Solow-Uzawa Growth Model. Rev. CEA 7.

Zhou, C., Xie, H., 2019. Does Fiscal Policy Promote Third-Party Environmental Pollution Control in China? An Evolutionary Game Theoretical Approach. 